\title{
Genetic similarity of natural populations and plantations of Pinus roxburghii Sarg. in Nepal
}

\author{
Archana GAULI ${ }^{1}$, Oliver GAILING ${ }^{1,2}$, Valdir Marcos STEFENON ${ }^{1,3}$, Reiner FINKELDEY $^{1 *}$ \\ ${ }^{1}$ Forest Genetics and Forest Tree Breeding, Büsgen-Institute, Georg-August University, Göttingen Büsgenweg 2, 37079 Göttingen, Germany \\ ${ }^{2}$ School of Forest Resources and Environmental Science, Michigan Technological University, USA \\ ${ }^{3}$ Federal University of the Pampa, São Gabriel, RS, Brazil
}

(Received 30 November 2008; accepted 5 April 2009)

Keywords:

genetic diversity /

genetic differentiation /

forest reproductive material /

nuclear microsatellites /

chloroplast microsatellites
Mots-clés :

diversité génétique /

différenciation génétique /

matériels forestiers reproducteurs /

microsatellites nucléaires /

microsatellites chloroplastiques

\begin{abstract}
- Genetic structures of five population pairs each consisting of one natural population and one neighbouring plantation of Pinus roxburghii Sarg. in Nepal were assessed using nuclear (nSSRs) and chloroplast microsatellite loci (cpSSRs).

- The mean number of alleles at nSSRs loci in natural populations was 5.0 compared to 4.93 in plantations while the average observed heterozygosities were the same in both groups $\left(H_{0}=0.50\right)$. Most of the alleles were common to all the populations, indicating that the populations correspond to a single genetic entity. Similarly forty-seven haplotypes were observed in natural populations compared to fifty haplotypes in plantations. Mean haplotype diversities of natural populations (0.953) and plantations (0.955) were very similar. Genetic diversity of Pinus roxburghii was relatively high with low or no evidence of inbreeding while genetic differentiation among all populations was very low (about $1 \%$ ).

- The very low differentiation among natural populations indicates efficient long- distance gene flow among populations resulting in homogeneous genetic structures at least at selectively neutral loci. Even though the harvest and production of seeds and seedlings was largely uncontrolled, genetic structures of most plantations show no signs of reduced variation, inbreeding or other negative effects compromising the adaptedness or adaptability of planted forests.
\end{abstract}

Résumé - Similitude génétique des populations naturelles et des plantations de Pinus roxburghii Sarg. au Népal.

- Les structures génétique de cinq paires de populations composées chacune d'une population naturelle et d'une plantation voisine de Pinus roxburghii Sarg. au Népal ont été évalués à l'aide de loci nucléaires (nSSRs) et de loci microsatellites chloroplastiques (cpSSRs).

- Le nombre moyen d'allèles à loci nSSRs dans les populations naturelles était de 5,0 comparé à 4,93 dans les plantations alors que la moyenne des hétérozygoties observées étaient les mêmes dans les deux groupes $\left(H_{0}=0,50\right)$. La plupart des allèles étaient communs à toutes les populations, indiquant que les populations correspondent à une seule entité génétique. De même, quarante-sept haplotypes ont été observés dans les populations naturelles par rapport à cinquante haplotypes dans les plantations. La diversité moyenne des haplotypes des populations naturelles $(0,953)$ et des plantations $(0,955)$ étaient très similaires. La diversité génétique de Pinus roxburghii a été relativement importante, avec peu ou pas de preuve de consanguinité tandis que la différenciation génétique entre les populations était très faible (environ $1 \%$ ).

- Le très faible différenciation entre les populations naturelles indique des flux de gènes efficaces à longue distance entre les populations issues de structures génétiques homogènes avec au moins une sélectivité neutre des loci. Même si la récolte et la production de semences et de plants ont été largement incontrôlées, les structures génétiques de la plupart des plantations ne montrent aucun signe de réduction de la variation de la consanguinité ou d'autres effets négatifs compromettant la faculté d'adaptation des forêts plantées.

\footnotetext{
*Corresponding author: rfinkel@gwdg.de
} 


\section{INTRODUCTION}

An understanding of the degree of diversity within and between populations of a species is required to support continuously rising plantation programs and to provide information for the conservation of the species' genetic resources since geographically separated populations are expected to have different genetic compositions (e.g. Sharma et al., 2002). Genetic diversity is of prime importance for species persistence (Wang and Szmidt, 2001), since the evolutionary adaptive potential of populations depends on genetic variation patterns (Finkeldey and Hattemer, 2007; Siregar, 2000). Within each tree species, the amount and distribution of genetic variation determine its evolutionary adaptability. Consequently, genetic variation is crucial for the long- term stability of forest ecosystems (Sharma et al., 2002).

Genetic structures of numerous plant populations have been altered by humans for many generations (Finkeldey and Hattemer, 2007). This applies in particular to tree species used for the establishment of plantations. Genetic structures of plantations are often assumed to strongly differ from natural stands, to exhibit reduced levels of genetic variation and, accordingly, reduced adaptive potentials in comparison to natural stands (e.g. Pandey et al., 2004). Reduced adaptability is particularly likely if seeds are harvested and seedlings are raised without appropriate control and in the absence of efficient legal regulations governing the marketing of forest reproductive material (Nason, 2001). Legislation on forest reproductive material is currently either not existing or poorly enforced in most developing countries. Thus, many routinely established plantations of tropical forest tree species are assumed to show low levels of genetic diversity, i.e. to exhibit a 'narrow genetic base', since reproductive material was harvested and raised uncontrolled. However, few studies examine the impact of the harvest of forest reproductive material and the raising of seedlings in nurseries on the genetic structures of the resulting plantations in subtropical and tropical regions.

Pinus roxburghii Sarg. is a wind-pollinated, monoecious subtropical pine species. It is found in a fairly continuous distribution throughout the monsoon belt between $72^{\circ} \mathrm{E}$ and $95^{\circ} \mathrm{E}$ longitude and $27^{\circ} \mathrm{N}$ and $35^{\circ} \mathrm{N}$ latitude; and is abundant on the hill slopes of both the western and eastern Himalayas between altitudes of $450 \mathrm{~m}$ to $2300 \mathrm{~m}$ above sea level (Arya et al., 2000). Naturally, it is distributed from Bhutan (only in drier areas), Northern India (Jammu and Kashmir, Punjab, Himanchal Pradesh, Uttarakhand, Sikkim), Nepal, south of Tibet and Pakistan to Afghanistan (Dogra, 1985; Yi and Raven, 1999).

P. roxburghii has outnumbered all other species in afforestation programs in its natural zone of occurrence. It is by far the most widely planted forest tree species both in government managed forests and community forests in Nepal. It comprises $17 \%$ of the total forest area of Nepal. It is also a species widely planted by individual farmers because of its high survival rate and ease of plantation establishment and management (Jackson, 1994). However, the origin of plant material for plantations is usually unknown.
In this study, the genetic structure of $P$. roxburghii was assessed using nuclear and chloroplast microsatellite markers. The central objective of the study was to assess the genetic variation within natural populations of $P$. roxburghii in Nepal and to compare results with variation patterns in plantations. Four hypotheses were formulated: (i) the different origin of natural and planted populations is reflected by different genetic structures; (ii) plantations show lower levels of genetic variation than natural populations due to bottlenecks during the harvesting of reproductive material and raising of seedlings; (iii) genetic differentiation between plantations and neighboring natural populations is high; and (iv) genetic variation is spatially structured in natural populations, i.e. distantly located natural populations are genetically more differentiated from each other than neighboring populations, but not in plantations.

\section{MATERIALS AND METHODS}

\subsection{Plant material and DNA extraction}

Five pairs of natural (NR) and planted (PL) populations were selected from four different development regions throughout the natural distribution range of P. roxburghii in Nepal in order to have a population sample that is representative for the whole country both for natural forests and plantations. Population pairs were selected on the basis of pair availability. Both populations from the same pair were located in similar altitudes and experienced similar climatic conditions. The distance between two populations from the same pair varied from $1 \mathrm{~km}$ to $5 \mathrm{~km}$. Populations were sampled in (1) Dadeldhura (1745 m asl), (2) Salyan (1457 m asl), (3) Palpa (1350 m asl), (4) Parbat (946 m asl), and (5) Bhaktapur (2 $163 \mathrm{~m}$ asl) (Fig. 1).

Forty trees from each population were sampled. The first tree was selected randomly and the next at the distance of double tree height of the previous sampled tree. Twigs with terminal buds were collected from individual trees and were packed separately in small labelled plastic bags. DNA was extracted from needles using the DNeasy 96 Plant Kit (Qiagen). DNA extraction followed the protocol of the supplier.

\subsection{PCR amplification for nuclear microsatellites markers}

Eight nuclear microsatellites (nSSRs) PtTX2123, PtTX3020, PtTX3025, PtTX3118, PtTX3030, PtTX3107 (Auckland et al., 2002), LOP1 and LOP3 (Liewlaksaneeyanawin et al., 2004) were selected for the study. Polymerase Chain Reaction (PCR) for PtTX2123, PtTX3020, PtTX3025, PtTX3118, PtTX3030 and PtTX3107 was performed in a $15 \mu \mathrm{L}$ volume containing about $20 \mathrm{ng}$ DNA, $1 \times$ Qiagen PCR buffer, $2.5 \mathrm{mM}$ of $\mathrm{MgCl}_{2}, 0.5 \mathrm{mM}$ of each dNTPs, $0.67 \mu \mathrm{M}$ of each forward and reverse primers, $0.5 \times \mathrm{Q}$ solution (Qiagen) and $1 \mathrm{U}$ of Taq polymerase (Qiagen). Each forward primer was labelled with blue (6-FAM) or green (HEX) fluorescent dyes. PCR for LOP1 and LOP3 was performed in a $10 \mu \mathrm{L}$ volume containing $20 \mathrm{ng}$ DNA, $1 \times$ Qiagen PCR buffer, $1.5 \mathrm{mM}$ of $\mathrm{MgCl}_{2}, 0.5 \mathrm{mM}$ of each dNTP, $0.67 \mu \mathrm{M}$ of each forward and reverse primers, $0.67 \times \mathrm{Q}$ solution 


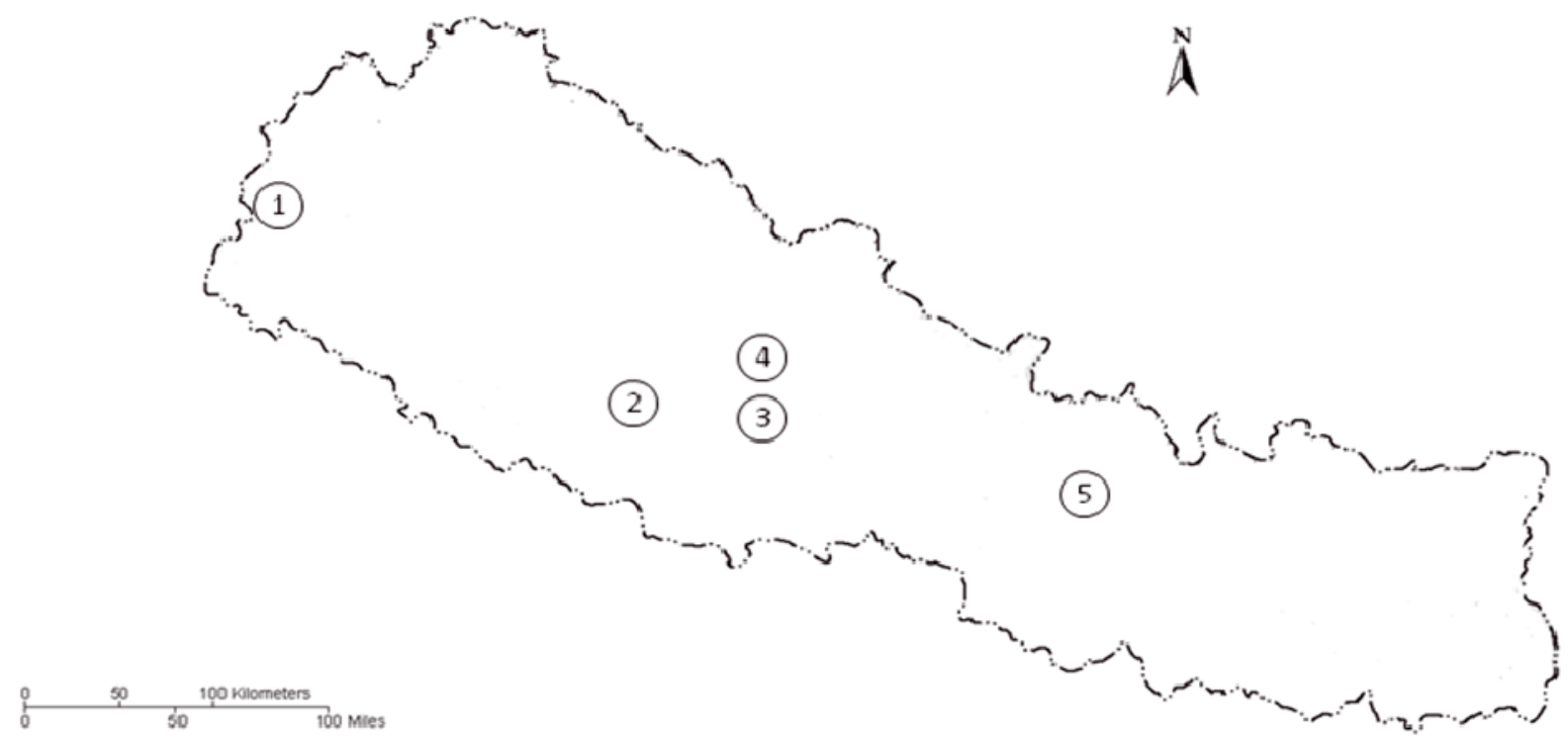

Figure 1. Map of Nepal showing locations of investigated population pairs. (1): Dadeldhura natural population and Dadeldhura plantation, (2): Salyan natural population and Salyan plantation, (3): Palpa natural population and Palpa plantation, (4): Parbat natural population and Parbat plantation, (5): Bhaktapur natural population and Bhaktapur plantation.

(Qiagen) and $1 \mathrm{U}$ of Taq polymerase (Qiagen). The PCR amplification was carried out in a Peltier Thermal Cycler PTC -200 (MJ Research). The PCR profile consisted of $15 \mathrm{~min}$ denaturation at $95{ }^{\circ} \mathrm{C}$ with 5 cycles of denaturation at $94{ }^{\circ} \mathrm{C}$ for $1.3 \mathrm{~min}, 55^{\circ} \mathrm{C}$ annealing for $1.3 \mathrm{~min}$ and $72{ }^{\circ} \mathrm{C}$ extension for $1.3 \mathrm{~min}$, decreasing $1{ }^{\circ} \mathrm{C}$ per cycle followed by 33 cycles of denaturation at $94{ }^{\circ} \mathrm{C}$ for $1.3 \mathrm{~min}, 50{ }^{\circ} \mathrm{C}$ annealing for $1.3 \mathrm{~min}$ and $72{ }^{\circ} \mathrm{C}$ extension for $1.3 \mathrm{~min}$ followed by the final extension of $72{ }^{\circ} \mathrm{C}$ for $10 \mathrm{~min}$. For LOP 1 and 3, the PCR profile consisted of $15 \mathrm{~min}$ denaturation at $95^{\circ} \mathrm{C}$, followed by $30 \mathrm{cy}$ cles of denaturation at $94{ }^{\circ} \mathrm{C}$ for $1 \mathrm{~min}, 60^{\circ} \mathrm{C}$ annealing for $1 \mathrm{~min}$ and 1 min extension at $72{ }^{\circ} \mathrm{C}$, with final extension at $72{ }^{\circ} \mathrm{C}$ for $8 \mathrm{~min}$.

\subsection{PCR amplification for chloroplast microsatellite markers}

The four chloroplast microsatellite loci Pt71936, Pt63718, Pt87268 and Pt15169 (Vendramin et al., 1996) were used for the study. PCR amplification was performed in a $15 \mu \mathrm{L}$ volume containing $1 \times$ Qiagen PCR buffer, $2.5 \mathrm{mM}$ of $\mathrm{MgCl}_{2}, 0.5 \mathrm{mM}$ of each dNTP, $0.67 \mu \mathrm{M}$ of each forward and reverse primer, $1 \mathrm{U}$ of Taq polymerase (Qiagen) and about 20 ng DNA. Each forward primer was labelled with blue (6-FAM) or green (HEX) fluorescent dyes. Amplification was carried out in a Peltier Thermal Cycler PTC -200 (MJ Research). PCR amplification followed the method described by Vendramin et al. (1996) with slight modifications. The PCR profile consisted of 15 min denaturation at $95{ }^{\circ} \mathrm{C}, 8 \mathrm{~min}$ enzyme addition at $80{ }^{\circ} \mathrm{C}$, followed by 25 cycles of denaturation at $94{ }^{\circ} \mathrm{C}$ for $1 \mathrm{~min}$, annealing at $58^{\circ} \mathrm{C}$ for $1 \mathrm{~min}$ and $1 \mathrm{~min}$ extension at $72{ }^{\circ} \mathrm{C}$, with a final extension step at $72{ }^{\circ} \mathrm{C}$ for $8 \mathrm{~min}$.

\subsection{Fragment analysis}

Amplified PCR products were diluted according to their intensity after agarose gel electrophoresis and were then run on the
ABI PRISM Genetic Analyser 3100, with the internal size standard GS 500 ROX (Applied Biosystems). Data were analysed using Genescan 3.7 and Genotyper 3.7 softwares (Applied Biosystems).

\subsection{Data Analysis}

\subsubsection{Analysis of nuclear microsatellites}

For the analysis of nSSR data, allelic and genotypic frequencies, effective numbers of alleles ( $\mathrm{Ne}$; Nei, 1975), observed and expected heterozygosity (Ho and $\mathrm{He}$ respectively; Nei, 1975) and fixation in$\operatorname{dex}(F$; Wright, 1965) were calculated using GenAlEx6 (Peakall and Smouse, 2005). Overall $F_{\mathrm{ST}}$ (Weir and Cockerham, 1984) was estimated using the software FSTAT version 2.9.3 (Goudet, 2001). Because of its dependence on the level of genetic variation a standardized genetic differentiation measure was calculated according to Hedrick (2005). Pairwise $F_{\mathrm{ST}}$ values were calculated according to Wright (1965) using the software Arlequin (Excoffier et al., 2005).

A non- hierarchical analysis of molecular variance (AMOVA; Excoffier et al., 1992) was applied to estimate within and among population differentiation for natural populations and plantations and between population types (natural and planted). Significance tests were performed by 1023 permutations.

Genetic distance matrices and UPGMA dendrograms were computed based on Nei's genetic distance (Nei, 1972) using the software POPULATIONS 2.0 (Langela, 2002). Statistical support was assessed by means of 1000 bootstrap replicates over loci.

Mantel tests (Mantel, 1967) were performed using the software NTSYS-pc version 2.0 (Rohlf, 1998) and GenAlEx6 (Peakall and Smouse, 2005) in order to test for a significant correlation between the matrix of geographic and genetic distances within the group of natural populations and plantations, respectively. 

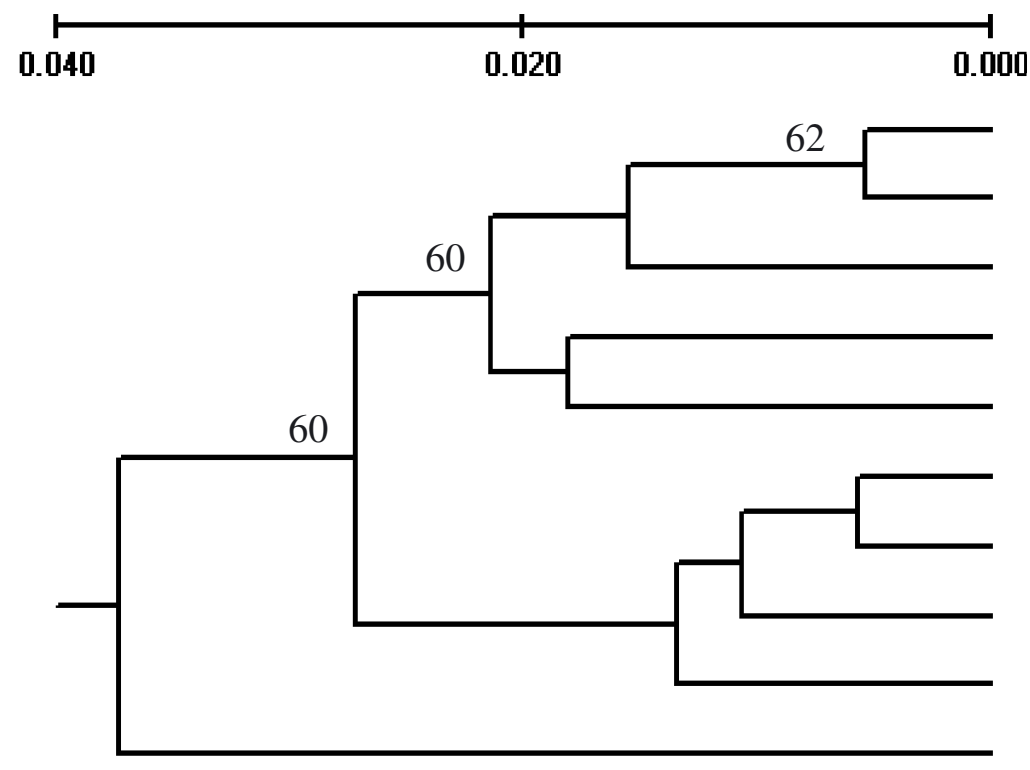

Dadeldhura NR

Bhaktapur PL

Parbat PL

Salyan NR

Salyan PL

Palpa NR

Palpa PL

Parbat NR

Bhaktapur NR

Dadeldhura PL

Figure 2. UPGMA dendrogram based on Nei (1972) minimum genetic distance between all studied natural populations and plantations (nSSRs). Bootstrap values based on 10000 permutations (only bootstrap values above 50) are indicated in each node.

\subsubsection{Analysis of chloroplast microsatellites}

The multilocus genotypes observed at the two polymorphic cpSSRs were jointly interpreted as haplotypes. Chloroplast haplotype variation within populations was calculated by estimating the total number of haplotypes $N$ by direct count, the effective number of haplotypes (Ne: Nei, 1978), haplotype diversity as the probability that two haplotypes chosen at random from a population are different $(h \leq 1$ : Nei, 1978) and genetic distance $(D ;$ Nei, 1978) using GenALEx6 (Peakall, and Smouse, 2005) software.

For the clustering analysis, Nei's standard genetic distance (Nei, 1978) was calculated for each pair of populations using AFLP-SURV (Vekemans, 2002) and the dendrogram was constructed with the programs NEIGHBOUR (UPGMA algorithm) and CONSENSE (expanded majority rule approach) of the package PHYLIP (Felsenstein, 1989) release 3.66. Statistical support of the clusters was assessed by means of 1000 bootstrap replicates over loci. Analysis of molecular variance and Mantel tests were conducted as described for nSSRs.

\section{RESULTS}

\subsection{Nuclear microsatellites}

Out of eight nSSR loci tested in 16 samples from all populations, seven amplified, and one (PtTX3025) failed to amplify. Among these seven loci, four (PtTX3020, PtTX3118, PtTX3030 and LOP3) were monomorphic and three (PtTX2123, PtTX3107 and LOP1) revealed polymorphisms. The results are based on the three polymorphic loci.

\subsection{Genetic variation within populations}

At the three analysed loci, 23 alleles were detected with an average of 7.66 alleles per locus in natural populations.
Slightly lower variation, i.e. 21 alleles with an average of 7 alleles per locus, was observed in plantations. A summary of the genetic variation parameters for each of the three nuclear microsatellites and for each of the populations as well as mean values over all loci are given in Table I. The mean effective number of alleles in natural populations ranged from 2.21 (Parbat) to 2.74 (Salyan), in plantations it ranged from 2.24 (Parbat) to 2.85 (Salyan). In natural populations, observed heterozygosity $(\mathrm{Ho}$ ) for all loci ranged from 0.45 (Palpa) to 0.55 (Salyan) with a mean value of 0.50 . Within plantations, Ho ranged from 0.42 (Palpa) to 0.54 (Dadeldhura) with a mean value of 0.50 as well. In natural populations, expected heterozygosity $(\mathrm{He})$ for nSSRs loci varied from 0.50 (Parbat and Dadeldhura) to 0.56 (Salyan) with a mean value of 0.52 . In plantations $\mathrm{He}$ ranged from 0.49 (Palpa) to 0.56 (Bhaktapur) with the same mean value as in natural populations. The mean values of the fixation indices for three populations (Bhaktapur NR, Dadeldhura PL and Parbat PL) were slightly negative. For most of the populations fixation indices were close to zero. Only the natural and planted population from Palpa showed high and positive fixation indices of 0.17 and 0.18 , respectively.

\subsection{Genetic differentiation among populations}

Genetic distances ranged from 0.005 between Dadeldhura NR and Bhaktapur PL to 0.048 between Dadeldhura PL and Parbat PL. All genetic distances between populations were low with an average of 0.026 . The UPGMA dendrogram based on Nei's (1972) genetic distance (Fig. 2) showed there was no clear grouping of population pairs (natural/ planted) from one region. For most clades there was only low (non-significant) bootstrap support. Clusters with significant bootstrap support 
Table I. Summary of genetic variation parameters at three nuclear microsatellites for each natural and planted population.

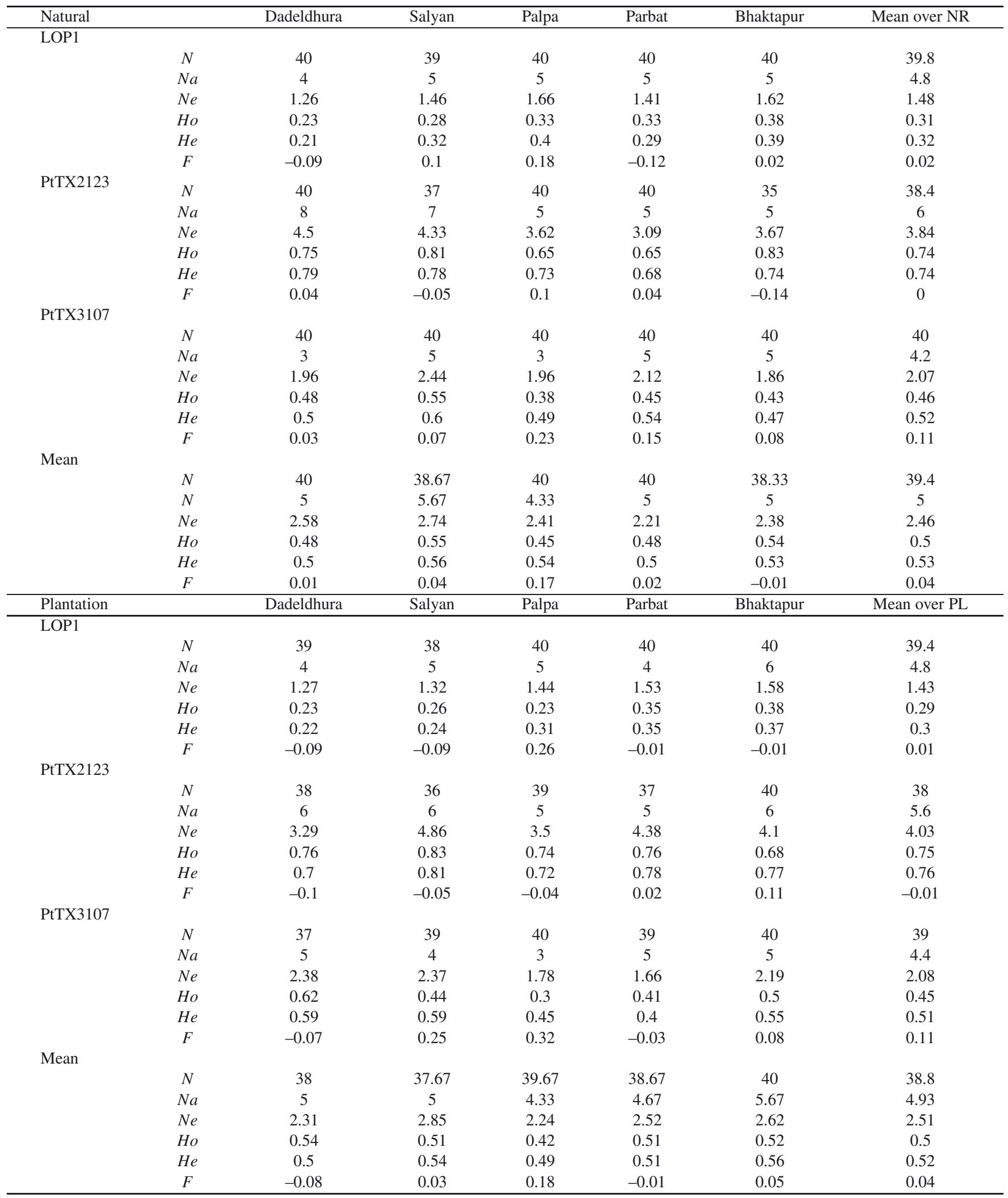

$N$ : sample size; $N a$ : number of alleles; $N e$ : effective number of alleles; $H o$ : observed heterozygosity; $H e$ : expected heterozygosity; $F$ : fixation index. 
Table II. Summary of the non-hierarchical analysis of molecular variance (AMOVA) for natural populations and plantations at nSSRs.

\begin{tabular}{lccccc}
\hline $\begin{array}{l}\text { Source of } \\
\text { variation }\end{array}$ & $d f$ & $\begin{array}{c}\text { Sum of } \\
\text { squares }\end{array}$ & $\begin{array}{c}\text { Variation } \\
\text { component }\end{array}$ & variation & $p$ value \\
\hline Among groups & 1 & 1.029 & 0.000 & $0 \%$ & 0.66569 \\
$\begin{array}{l}\text { Among population } \\
\text { within groups }\end{array}$ & 8 & 10.838 & 0.008 & $1 \%$ & $<0.05$ \\
$\begin{array}{l}\text { Within population } \\
788\end{array}$ & 591.046 & 0.750 & $99 \%$ & $<0.001$ \\
\hline
\end{tabular}

$d f$ : degree of freedom; $p$ value: the probability of obtaining a more extreme component estimate by chance.

( $>$ 50) are marked in Figure 2. Considering the five studied natural populations, the Mantel test revealed no significant correlation of genetic and geographic distances for both natural populations $(r=0.1814, P=0.6869)$ and plantations $(r=0.2105, P=0.340)$.

The proportion of the total genetic variation distributed among populations computed using $F_{\mathrm{ST}}$ was $0.6 \%$ (standardized $F_{\mathrm{ST}}=1.95 \%$ ) for natural populations and $1.4 \%$ (standardized $F_{\mathrm{ST}}=4.43 \%$ ) for plantations. AMOVA revealed that only $1.0 \%$ of the total genetic variation occurred among populations in both populations types. AMOVA among the two groups (natural populations and plantations) revealed virtually no differentiation between the groups (Tab. II). Pairwise $F_{\text {ST }}$ values between populations ranged from -0.008 to 0.032 and were in most cases not significant (Tab. V).

\subsection{Chloroplast microsatellites}

A subset of two out of four analyzed cpSSR loci, namely Pt71936 and Pt87268, was polymorphic and used for further analyses.

\subsection{Genetic variation within populations}

For chloroplast microsatellites, 60 different haplotypes were observed. A total of 47 haplotypes and 50 haplotypes were observed in natural populations and plantations, respectively. A summary of chloroplast haplotype variation analyzed at two cpSSR loci is given in Table III. The average effective number of haplotypes was 14.34 for natural populations and 15.65 for plantations. Haplotypic diversity was very high in all populations. In natural populations it ranged from 0.942 (Bhaktapur NR) to 0.969 (Dadeldhura NR) with a mean haplotypic diversity of 0.953 . In plantations it ranged from 0.922 (Parbat PL) to 0.983 (Dadeldhura PL) with a mean haplotypic diversity of 0.955 .

\subsection{Genetic differentiation among populations}

Genetic distance ranged from 0.22 between Parbat NR and Bhaktapur PL to 1.19 between Palpa NR and Bhaktapur NR. The UPGMA dendrogram based on genetic distances between populations showed no association with geographic origin
Table III. Summary of chloroplast haplotype variation at two cpSSR loci.

\begin{tabular}{lcccc}
\hline & $N$ & $N a$ & $N e$ & $h$ \\
\hline Natural & & & & \\
\hline Dadeldhura & 40 & 22 & 18.18 & 0.969 \\
Salyan & 37 & 21 & 12.56 & 0.946 \\
Palpa & 39 & 24 & 15.36 & 0.960 \\
Parbat & 40 & 19 & 13.56 & 0.950 \\
Bhaktapur & 38 & 17 & 12.03 & 0.942 \\
Mean & 38.8 & 20.6 & 14.34 & 0.953 \\
\hline Plantation & & & & \\
\hline Dadeldhura & 40 & 28 & 24.24 & 0.983 \\
Salyan & 38 & 22 & 16.79 & 0.966 \\
Palpa & 39 & 21 & 13.00 & 0.947 \\
Parbat & 37 & 17 & 9.71 & 0.922 \\
Bhaktapur & 39 & 22 & 14.49 & 0.955 \\
Mean & 38.6 & 22.0 & 15.65 & 0.955 \\
\hline
\end{tabular}

$N$ : sample size; $N a$ : number of haplotypes; $N e$ : effective number of haplotypes; $h$ : haplotype diversity.

Table IV. Summary of the non-hierarchical analysis of molecular variance (AMOVA) at cpSSRs.

\begin{tabular}{lccccc}
\hline $\begin{array}{l}\text { Source of } \\
\text { variation }\end{array}$ & $d f$ & $\begin{array}{c}\text { Sums of } \\
\text { square }\end{array}$ & $\begin{array}{c}\text { Variation } \\
\text { component }\end{array}$ & $\begin{array}{c}\% \\
\text { variation }\end{array}$ & $p$ value \\
\hline Among groups & 1 & 2.97 & 0.006 & 0.35 & 0.1476 \\
$\begin{array}{l}\text { Among populations } \\
\text { within groups }\end{array}$ & 8 & 15.14 & 0.008 & 0.48 & 0.14 \\
$\begin{array}{l}\text { Within populations } \\
\text { (377 }\end{array}$ & 601.43 & 1.595 & 99.18 & 0.06 \\
\hline
\end{tabular}

$d f$ : degree of freedom; $p$ value: the probability of obtaining a more extreme component estimate by chance.

(Fig. 3). Planted and natural populations from the same region are found in different clusters of the dendrogram. For all clusters there is only low (non-significant) bootstrap support $(<50)$. Mantel tests showed no significant correlation between geographical and genetic distances for both natural populations $(r=0.3761, P=0.8052)$ and plantations $(r=0.5626$, $P=0.100)$.

Analysis of molecular variance (Tab. IV) showed a high proportion of variation within populations. Less than $1 \%$ of the total genetic variation occurred among populations demonstrating a very low population differentiation $\left(F_{\mathrm{ST}}=0.008\right)$. Also a very low differentiation of only $0.35 \%$ was found among the two groups (natural populations and plantations).

\section{DISCUSSION AND CONCLUSION}

\subsection{Genetic variation within populations}

We found moderate levels of genetic diversity within populations of P. roxburghii in Nepal at nuclear SSRs and high diversity of chloroplast haplotypes. Previous reports on the diversity of the species were based on isozymes (Hussain, 1995; Sharma et al., 2002) and used material from other regions of 


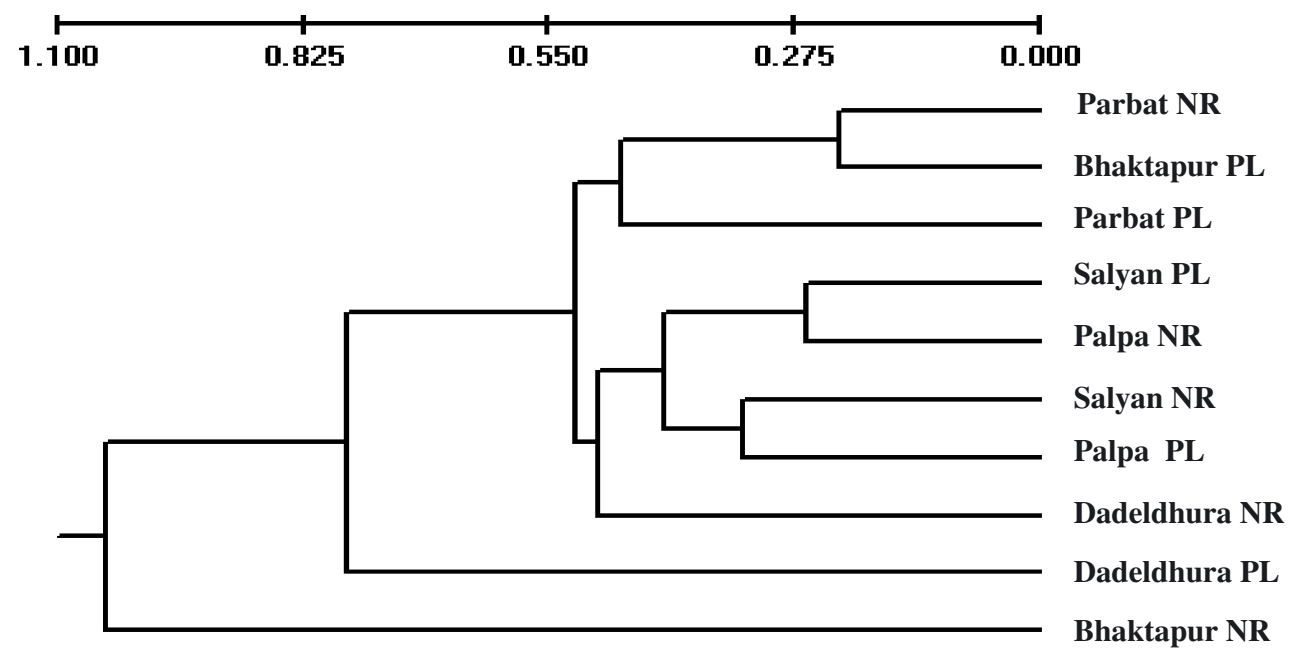

Figure 3. UPGMA dendrogram based on Nei (1978) genetic distance between all studied natural populations and plantations (cpSSRs). Bootstrap values based on 10000 permutations (only bootstrap values above 50) are indicated in each node.

Table V. Pairwise $F_{\mathrm{ST}}$ and significant $p$ values for the investigated ten populations (nSSRs).

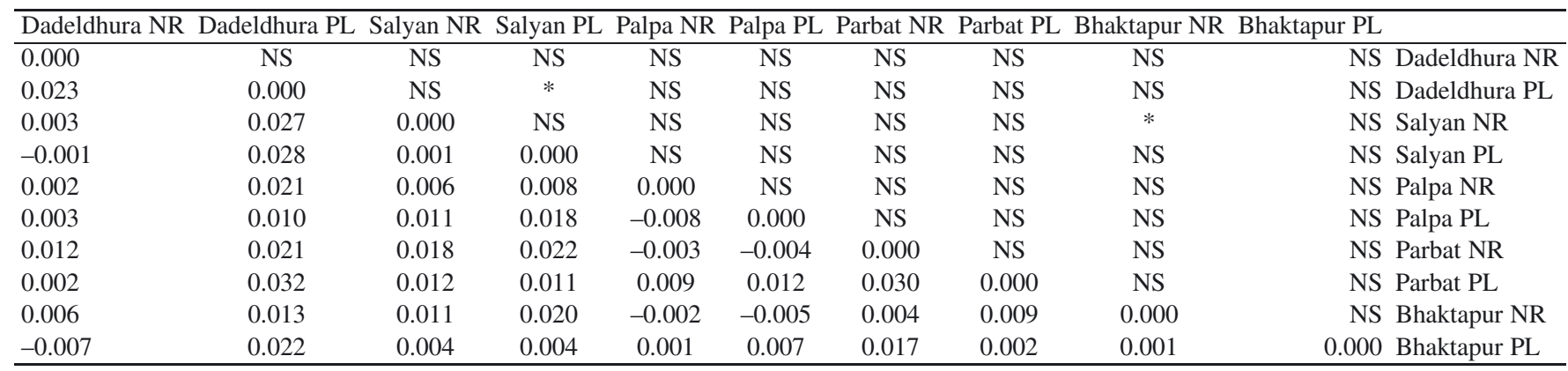

NS: non significant $*$ significant at $5 \%$.

the natural distribution of the species. These studies revealed high diversity within populations at isozyme gene loci. A direct comparison of results based on isozyme and nuclear SSR gene markers is not meaningful even though both marker types show co-dominant inheritance due to the typically higher diversity observed at nuclear SSRs.

The assessment of genetic variation within populations at nSSRs often revealed higher (e.g. P. pinaster: Mariette et al., 2001; P. contorta: Thomas et al., 1999; P. canariensis: Navascus and Emerson, 2007) or comparable (e.g. Pinus strobus: Marquardt et al., 2007) estimates to other pines. We investigated only three SSR loci, which were among other criteria selected due to their comparatively high polymorphism observed in a preliminary survey using few genotypes only. On the other hand, the investigated loci were developed for Pinus taeda and transferred to P. roxburghii, and LOP1 was developed from EST sequences. The polymorphism level is often lowered if a SSR marker is transferred to another species in comparison to the species used for SSR development (Weising et al., 2005) and selective constraints possibly restrict variation at SSRs in coding regions developed from EST sequences (Rungis et al., 2004).
While the conclusion of 'moderate' levels of genetic diversity in the natural populations of $P$. roxburghii in Nepal at nuclear genes is preliminary due to the low number of investigated SSRs and the considerations mentioned above, the large number of cpDNA haplotypes clearly indicates high diversity of the chloroplast genome, even though only two highly polymorphic cpSSRs were investigated. On average more than 20 haplotypes were identified in samples with a mean size of less than 40 trees per population. Because of their uniparental inheritance the effective population size of chloroplast genomes is half of nuclear diploid genomes.

Thus, cpDNA markers are expected to show stronger negative effects of reduced population sizes on diversity levels within populations in comparison to biparentally inherited nuclear markers (McCauley, 1995; Navascués and Emerson, 2007). Our results indicate that the genetic structures of the natural populations were not strongly affected by bottlenecks and genetic drift in their recent evolutionary past.

One of the main objectives of this study was the comparison of variation levels in natural and planted populations. Absolute levels of diversity are less important in this context. The average number of alleles per population was slightly lower in 
plantations (4.93) than in natural populations (5.0) at nSSRs while the average observed heterozygosity was identical (0.50) in both population types. The average number of cpDNA haplotypes is even higher in plantations than in natural populations in contrast to results by Navascués and Emerson (2007) who investigated natural and artificially regenerated stands with unknown origin of $P$. canariensis. Thus, we reject hypothesis (ii) according to which the variation levels in plantations are lower than in natural populations. Neither the mode of seed harvest nor selective effects prior to or after the establishment of plantations caused noticeable losses of diversity at the observed nuclear gene markers or chloroplast haplotypes (see below). No significant impact of the regeneration method (natural regeneration versus plantation) on levels of genetic diversity at nSSRs was also reported by Thomas et al. (1999) for $P$. contorta.

Inbreeding coefficients (fixation indices $F$ ) were close to 0 and sometimes even negative within both plantations and natural populations. However, comparatively high fixation indices were observed in the population pair Palpa (mean $F=0.17$ for the natural population and mean $F=0.18$ for the plantation). The observation of positive and rather homogeneous fixation indices at the three investigated nSSRs in the natural population Palpa suggests that inbreeding due to elevated levels of selfing or biparental mating is a possible cause of the positive $F$-values (Tab. I). A negative fixation index was observed at locus PtTX2123 in the plantation Palpa raising doubts that inbreeding caused the high fixation indices at the remaining two loci in this population. Other causes such as the occurrence of mutations at the primer binding sites next to one or more SSRs causing 'null alleles' with higher frequencies in the Palpa populations than in other stands cannot be ruled out.

\subsection{Genetic variation among populations}

Approximately $99 \%$ of the total variation resided within populations both at nSSRs and at cpDNA haplotypes. Accordingly, differentiation among populations is extraordinary low.

Low differentiation among natural populations is frequently observed at neutral marker loci for conifers and other windpollinated trees forming large, more or less continuous stands (Hamrick et al., 1992). Gene flow mainly through pollen and longevity are the main evolutionary factors responsible for the lack of strong differentiation among wind-pollinated trees (Austerlitz et al., 2000). Thus, extensive pollen-mediated gene flow is likely to be the main cause for the absence of significant differentiation among natural populations. Since no significant spatial structure was observed among natural populations, hypothesis (iv) is rejected. Efficient movement of pollen causes not only low differentiation among populations, but also prevents significant correlations between spatial and genetic structures at neutral markers in natural populations of $P$. roxburghii in Nepal.

Differentiation was also very low between natural populations and plantations. Genetic structures of plantations are very similar to those of natural populations, and genetic distances between natural populations and neighbouring plantations are as low as those between natural stands and more distant plantations. Thus, we also reject hypothesis (i), since the two population types natural populations and plantations are not significantly differentiated from each other, and hypothesis (iii) since genetic distances between neighbouring plantations and natural populations are small. The origin of a stand (natural or planted) has no main impact on its genetic structures at the investigated loci.

\subsection{Genetic consequences of plantation establishment}

The establishment of the plantations had no noticeable effects on the genetic structures of the established man-made forests in comparison to natural stands. In particular, genetic diversity was not or only slightly reduced at nuclear microsatellites and chloroplast haplotypes. This result is mainly due to the low differentiation observed among natural stands as potential origins, and due to the mode of harvesting and production of seeds and seedlings for plantation establishment.

Natural stands are main sources for forest reproductive material in the absence of an advanced tree improvement programme for a plantation species in a particular region. The very low differentiation observed at the investigated gene markers makes it impossible to reliably identify the actual seed production areas used for seed harvesting operations in Nepal. However, our results do not support the idea that long-distance transport of forest reproductive material was involved in the establishment of the plantations. Even though the origin of the plantations cannot be identified, import of seeds from widely separated areas not covered in this survey or even other countries seems unlikely.

The mode of seed harvest and in particular the number of seed trees is of crucial importance for the genetic structure of the resulting plantations. The high diversity observed in all plantations and the low differentiation among the investigated populations strongly suggest that a high effective number of seed trees contributed to the planted progenies in all plantations, since a low number of seed trees inevitably results in decreased diversity and stronger differentiation among populations due to drift effects.

Mixing of material from several source populations potentially increases the diversity of plantations (Stefenon et al., 2008). However, the increase of diversity depends on the differentiation among source populations and disappears if populations are not differentiated from each other. Mixing of seeds from several poorly differentiated populations cannot be ruled out and may potentially contribute to the presumably large effective number of mother trees used for the production of seeds.

The similarity of genetic structures in planted and natural populations is in striking contrast to a study on genetic variation patterns of another important forest tree species in Nepal, Dalbergia sissoo. Pandey et al. (2004) also investigated five population pairs of $D$. sissoo consisting of a natural population and a neighbouring plantation in Nepal. They found almost complete differentiation between the groups of natural 
and planted populations at maternally inherited cpDNA haplotypes. In addition, polymorphism was observed at a single isozyme gene locus $(G d h-\mathrm{A})$ in all natural populations, but all plantations were fixed on a single allele. Pandey et al. (2004) interpreted their results as a strong hint towards the importance of long-distance transfer of forest reproductive material for the establishment of D. sissoo plantations in Nepal. Material was possibly imported from India. The susceptibility of $D$. sissoo plantations in Nepal to diseases is likely to be related to the use of reproductive material which was transported over long distances and hence might be poorly adapted to the environmental conditions in Nepal.

The exact origin of plantations is unknown for both species and seed harvesting was not monitored. Strong differences between genetic structures of natural versus planted stands were observed for $D$. sissoo. The adaptive potential of plantations is likely to be negatively affected for this species. However, no comparable effects of plantation establishment on genetic structures were observed for $P$. roxburghii.

Uncontrolled production of seeds and seedlings is a main problem for plantation forestry not only in Nepal, but also in most tropical countries. The origin of most tree plantations in the tropics is unknown, which often raises concerns about the adaptive potential of man-made forests (Finkeldey and Hattemer, 2007). The comparison of the results described here to the study by Pandey et al. (2004) shows that uncontrolled seed harvest, production of seeds, and marketing of reproductive material has very different consequences for the genetic structures of the established plantations. It is neither justified to assume a 'narrow genetic base' for all plantations of tropical trees with unknown origin, nor is it wise to neglect the potential consequences of uncontrolled seed harvest for the adaptedness and adaptability of man-made forests (Finkeldey and Hattemer, 2007).

\subsection{Conservation of genetic resources}

P. roxburghii is the most important forest tree species in Nepal. It is frequently planted and accordingly not in danger of immediate extinction in the country. However, genetic resources are possibly lost due to human impact such as fragmentation of natural forests and unsustainable resin tapping. In addition, large-scale afforestation and reforestation is expected to irreversibly modify genetic structures not only of newly established plantations, but also of surrounding remnants of natural forests by gene flow mainly through pollen from planted stands (Ellstrand, 1992).

Our results indicate that risks arising from plantation establishment for the genetic resources of $P$. roxburghii in Nepal are possibly low. Variation levels and genetic structures of all investigated plantations and natural forests are similar. This suggests that even plantations might qualify as gene conservation stands.

These conclusions are based on a small number of presumably selectively neutral gene markers, and refer to a set of five population pairs only. Similar genetic structures, in particular low differentiation among planted and natural popu- lations, are also expected at other neutral gene loci and in most other populations growing under comparable conditions in Nepal. However, stronger differentiation may be expected at loci under selection due to different environmental conditions. The conservation of the variation at these currently unknown "adaptive" gene loci is of particular concern. Thus, we propose to establish at least four areas for the in situ conservation of genetic resources in Nepal, one in each of the main growing regions of the species in the country, to capture also possibly existing 'hidden' variation at adaptive gene loci.

As shown above, a large number of genetically highly variable $P$. roxburghii plantations exist in Nepal. The phenotypically best plantations should be developed into seed production areas as a first step towards an operational tree improvement programme and as ex situ conservation stands. We recommend to assess the diversity of selected in situ and ex situ conservation stands at marker loci or to select natural or planted populations included in this study in order to safely avoid a focus of costly conservation measures on populations with low diversity.

Acknowledgements: The financial support of the German Academic Exchange Service (DAAD) to the first author is gratefully acknowledged. We thank Dr. N.-G. Eliades, A. Dolynska and O. Artes for advice in the laboratory and their skillful assistance during the lab work.

\section{REFERENCES}

Arya S., Kalia R.K., and Arya I.D., 2000. Induction of somatic embryogenesis in Pinus roxburghii Sarg. Plant Cell Rep. 19: 775-780.

Auckland L.D., Bui T., Zhou Y., Shepherd M., and Williams C.G., 2002. Conifer microsatellite handbook, Corporate Press, Raleigh, N.C.

Austerlitz F., Mariette S., Machon N., Gouyon P.-H., and Godelle B., 2000. Effects of colonization processes on genetic diversity: differences between annual plants and tree species. Genetics 154: $1309-1321$.

Dogra P.D., 1985. Conifers of India and their wild gene resources in relation to tree breeding. Ind. For. 111: 935-955.

Ellstrand N.C., 1992. Gene flow by pollen: implications for plant conservation genetics. Oikos 63: 77-86.

Excoffier L., Laval G., and Schneider S., 2005. Arlequin ver. 3.1: an integrated software package for population genetics data analysis, evolutionary bioinformatics online.

Excoffier L., Smouse P.E., and Quattro J.M., 1992. Analysis of molecular variance inferred from metric distances among DNA haplotypes: application to human mitrochondrial DNA restriction data. Genetics 131: 479-491.

Felsenstein J., 1989. PHYLIP: phylogeny inference package (version 3.2). Cladistics 5: 164-166.

Finkeldey R. and Hattemer H.H., 2007. Tropical forest genetics, Springer, Berlin, Heidelberg.

Goudet J., 2001. FSTAT: A program to estimate and test gene diversities and fixation indices (Version 2.9.3.2), University of Lausanne, Switzerland.

Hamrick J.L., Godt M.J.W., and Sherman-Broyles S.L., 1992. Factors influencing levels of genetic diversity in woody plant species. New For. 6: 95-124.

Hedrick P.W., 2005. A standardized genetic differentiation measure. Evolution 59: 1633-1638. 
Hussain A., 1995. Untersuchungen zur genetischen Kontrolle von Isoenzym- Polymorphismen und zur genetischen Struktur von Pinus roxburghii SARG. Thesis for the degree of Doctor of Forestry Science at the Faculty of Forestry Sciences and Forest Ecology, Georg-August university of Göttingen, Germany.

Jackson J.K., 1994. Manual of Afforestation in Nepal (Part II), Department of Forest Research and Forest Survey, Kathmandu, Nepal.

Langella O., 2002. Populations (Version 1.2.28), CNRS, France.

Liewlaksaneeyanawin C., Ritland C.E., El-Kassaby Y.A., and Ritland R., 2004. Single-copy, species-transferable microsatellite markers developed from loblolly pine ESTs. Theor. Appl. Genet. 109: 361-369.

Mantel N.A., 1967. The detection of disease clustering and a generalized regression approach. Cancer Res. 27: 209-220.

Mariette S., Chagné D., Lézier C., Pastuszka P., Raffin A., Plomion C., and Kremer A., 2001. Genetic diversity within and among Pinus pinaster populations: comparison between AFLP and microsatellite markers. Heredity 86: 469-479.

Marquardt P.E., Echt C.S., Epperson B.K., and Pubanz D.M., 2007. Genetic structure, diversity, and inbreeding of eastern white pine under different management conditions. Can J. For. Res. 37: 2652-2662.

McCauley D.E., 1995. The use of chloroplast DNA polymorphism in studies of gene flow in plants. Trends Ecol. Evol. 10: 198-202.

Nason A., 2001. The new OECD scheme for the certification of forest reproductive material. Silvae Genet. 50: 177-280.

Navascués M. and Emerson B.C., 2007. Natural recovery of genetic diversity by gene flow in reforested areas of the endemic Canary Island pine, Pinus canariensis. For. Ecol. Manage. 244: 122-128.

Nei M., 1978. Estimation of average heterozygosity and genetic distance from a small number of individuals. Genetics 89: 583-590.

Nei M., 1972. Genetic distance between populations. Am. Nat. 106: 283-292.

Nei M., 1975. Molecular population genetics and evolution. In: Neuberger A., Tatum E.L. (Eds.), Frontier of biology Vol. 40, American Elsevier, New York.

Pandey M., Gailing O., Leinemann L., and Finkeldey R., 2004. Molecular markers provide evidence for long-distance planting material transfer during plantation establishment of Dalbergia sissoo Roxb. in Nepal. Ann. For. Sci. 61: 603-606.
Peakall R. and Smouse P.E., 2005. Genalex 6: genetic analysis in Excel. Population genetic software for teaching and research. Mol. Ecol. Notes 6: 288-295.

Rohlf F.J., 1998. NTSYS-pc version 2.0. Numerical taxonomy and multivariate analysis system, Exeter Software, Setauket, New York.

Rungis D., Berube Y., Zhang J., Ralph S., Ritland C.E., Ellis B.E., Douglas C., Bohlmann J., and Ritland K., 2004. Robust simple sequence repeats markers for spruce (Picea spp.) from expressed sequence tags. Theor. Appl. Genet. 109: 1283-1294.

Sharma K., Degen B., Wuehlisch G.V., and Singh N.B., 2002. Allozyme variation in eight natural populations of Pinus roxburghii Sarg. in India. Silvae Genet. 51: 246-253.

Siregar I.Z., 2000. Genetic aspects of the reproductive system of Pinus merkusii. Jungh. et de Vriese in Indonesia. Thesis for the degree of doctor of forestry science at the Faculty of Forestry Sciences and Forest Ecology, Georg-August University of Göttingen, Germany, Cuvillier Verlag Göttingen.

Stefenon V.M., Gailing O., and Finkeldey R., 2008. Genetic structure of plantations and the conservation of genetic resources of Brazilian pine (Araucaria angustifolia). For. Ecol. Manage. 255: 2718-2725.

Thomas B.R., Macdonald S.E., Hicks M., Adams D.L., and Hodgetts R.B., 1999. Effects of reforestation methods on genetic diversity of lodgepole pine: an assessment using microsatellite and randomly amplified polymorphic DNA markers. Theor. Appl. Genet. 98: 793-801.

Vekemans X., 2002. AFLP-SURV version 1.0. Laboratoire de génétique et écologie végétale, Université Libre de Bruxelles, Belgium.

Vendramin G., Lelli L., Rossi P., and Morgante M., 1996. A set of primers for the amplification of 20 chloroplast microsatellites in Pinaceae. Mol. Ecol. 5: 595-598.

Wang X.-R. and Szmidt A.E., 2001. Molecular Markers in Population Genetics of Forest Trees. Scand. J. For. Res. 16: 199-220.

Weir B.S. and Cockerham C.C., 1984. Estimating F-statistics for the analysis of population structure. Evolution 38: 1358-1370.

Weising K., Nybom H., Wolff K., and Kahl G., 2005. DNA Fingerprinting in Plants. Principles, methods, and applications, Taylor \& Francis, Boca Raton.

Wright S., 1965. The interpretation of population structure by $F$-statistics with special regard to systems of mating. Evolution 19: 395-420.

Yi W.Z. and Raven P.H., 1999. Flora of China, Vol. 4, Science Press, St. Louis, Missouri Botanical Garden, Beijing. 